\title{
Rate of Interest, Financial Liberalization \& Domestic Savings Behavior in Pakistan
}

\author{
Rehmat Ullah Awan, Rahila Munir, Zakir Hussain \& Falak Sher \\ Department of Economics, University of Sargodha, Pakistan \\ E-mail: awanbzu@gmail.com
}

\begin{abstract}
The study analyzes long run and short run association among the real rate of interest on deposits, financial liberalization, economic growth, terms of trade, real remittances by Pakistani emigrants and domestic savings behavior in Pakistan, using annual time series data for 1973-2007. ARDL Bounds Testing Approach has been applied for co-integration. To test integration order of the variables, DF-GLS and Ng-Perron Tests have been employed. The results reveal that the real interest rate, financial liberalization and economic growth positively affect domestic savings in Pakistan in the long run. The co-efficient of liberalization dummy is also positive and statistically significant, suggesting a need for increased liberalization and deregulation of interest rate for mobilization of savings. Conversely, the terms of trade and real remittances by Pakistani emigrants show negative relationship with domestic savings, supporting Complementarity Hypothesis of Mckinnon-Shaw (1973).
\end{abstract}

Keywords: ARDL Co-integration, Error Correction Model, Rate of Interest, Financial Liberalization, Domestic Savings

\section{Introduction:}

The role of interest rate and financial liberalization in the process of economic development has remained a debated issue in developing countries. Financial liberalization was directed to reduce regulatory control over the institutional instruments and activities of agents in the financial sector. It increased the investment and raised interest rates. The low productivity of different sectors of economy suggested that it was more profitable to reinvest in bank deposits, thus reducing investment in the low productivity sector.

The financial repression leads to unproductive allocation of capital, low rate of returns to savers, high costs of financial intermediation, and inhibits growth of an economy (Roubini and Martin, 1992).

McKinnon and Shaw (1973) showed that financial liberalization led to higher interest rates which equated the demand and supply of savings. The authors expressed their view that higher interest rates lead to increased savings and financial intermediation in improving the efficiency of savings and investment. The higher real interest rates increase the extent of financial intermediation which in turn raises the rate of economic growth in developing countries (Balassa, 1989).

The growth of any economy depends on capital accumulation, and this requires investment and an equal amount of saving to match it (Thirlwall, 2004).

Domestic savings comprise of public and private savings. The contribution of public savings in domestic savings is negligible. To encourage private savings, the real interest rates should be positive. The innovative saving schemes and investment bonds should be introduced to mobilize resources. The corporate savings in Pakistan are also low because of small size of the corporate sector. The increase in investment will generate its own savings, either through increase in output or through income redistribution in the long run.

Further, the private savings will be increased through liberalization of financial markets, greater financial intermediation, controlling inflation, channeling resources from informal sector and floatation of new shares, bonds etc. The government and corporate sectors will also be encouraged to improve their productivity. This is essential because factor productivity is low in all sectors of the economy.

Considerable regulatory reforms were introduced in Pakistan over the last two decades. Investment and import licensing, and most of the foreign exchange restrictions were removed, capital market regulations were simplified, price and credit controls were relaxed, and interest rates were deregulated (Kemal, 2002).

The financial reforms are likely to bring about considerable economic benefits, particularly through more effective mobilization of domestic savings and by efficient allocation of resources. Domestic savings had a very prominent role in order to sustain the growth of an economy because of increased external financial rigidity (Kasekende, et al. 1999). 
High real interest rate (on bank deposits) stimulates financial and total domestic savings and then stimulates the private investment (Athukorala, 1998). The deregulation policy of interest rate promoted the savings and investment and attained the efficient allocation of financial resources (Shrestha and Chowdhry, 2007).

The positive impact of real interest rate and real money balances on output growth rate exists which demonstrates the validity of McKinnon -Shaw Hypothesis about financial liberalization. The results have no structural break and show positive effect of real balances on output growth of Sri Lanka's economy due to financial liberalization (Ghatak, 1997).

Pakistan needs to achieve a saving rate that is broadly in line with the investment requirements. The key issue in boosting national savings is to increase public savings through a strong tax reform programme, including financial liberalization, which would initiate a virtuous circle of higher growth, bringing about further increase in private savings, especially the household savings.

The liberalization policies were initiated in Pakistan on the advice of IMF and World Bank in late 1980,s. This study is based on the complementarity hypothesis of McKinnon and Shaw who postulated that high deposit interest rates promote the savings and these savings finance the bank credit to the private sector which increases capital accumulation in an economy.

Rest of the study is organized as follows: Section 2 gives the data, model and methodological framework. Empirical results are provided in section 3 and conclusion with recommendations is drawn in section 4 .

\section{Data, Model and Methodological Framework:}

Annual time series data (1973-2007) for Pakistan, used in this study have been obtained from International Financial Statistics (IFS, 2007), State Bank of Pakistan, Statistical Year Book and Economic Survey of Pakistan, various issues.

To examine the long run as well as short run relationship among the real rate of interest on deposits, financial liberalization, economic growth, terms of trade, real remittances by Pakistani emigrants and domestic savings in Pakistan, an appropriate econometric model is required for empirical analysis. Most of the studies have used Johansen-Juselius (1992) and Engle-Granger (1987) Co-integration techniques to identify the long run Co-integration relationship. The former technique can be used only if all the variables are integrated of same order.

This study uses Bounds testing approach to Co-integration employed within the framework of Autoregressive Distributed Lag model (ARDL) developed by Pesaran, et al. (1997), as it can be applied with out considering the same order of integration of all variables i.e. either they are integrated of order $\mathrm{I}(0)$, I(1) or of mixed order.

The ARDL bounds test is based on the F-statistic, which has a non-standard distribution. Two critical bounds are given by Pesaran, et al. (1997) for Co-integration test. The lower critical bound assumes that all the variables are $\mathrm{I}(0)$, while the upper bound assumes all the variables to be I(1).

Consider the following Autoregressive Distributed Lag (ARDL) model:

where

$$
\phi(L, P) Y_{t}=\sum_{i=1}^{k} \beta_{i}\left(L, q_{i}\right) X_{i t}+\delta w_{t}+\mu_{t}
$$

$$
\begin{array}{r}
\phi(L, P)=1-\phi_{1} L-\phi_{2} L^{2}-\ldots . \phi_{p} L^{p} \\
\beta_{i}\left(L, q_{i}\right)=\beta_{i 0}+\beta_{i 1} L+\beta_{i 2} L^{2 i}+\ldots \ldots \ldots+\beta_{i q} L^{q i}
\end{array}
$$

$(i=1,2, \ldots . k)$

$\mathrm{L}$ is a lag operator such that $L Y_{t}=Y_{t-1}$ and $w_{t}$ is a $\mathrm{s} \times 1$ vector of deterministic variables such as the intercept term, dummy variables, and time trends etc. (Pesaran, et al. 1997).

Following Unrestricted Error Correction Model, the general form of ARDL is given as;

$$
\Delta \mathrm{Yt}=\beta_{0}+\lambda_{1} \mathrm{Y}_{\mathrm{t}-1}+\lambda_{2} \mathrm{X}_{\mathrm{t}-1}+\sum_{\mathrm{i}=1}^{\mathrm{k}} \beta_{3} \Delta \mathrm{Y}_{\mathrm{t}-\mathrm{i}}+\sum_{\mathrm{i}=1}^{\mathrm{k}} \beta_{4} \Delta \mathrm{X}_{\mathrm{t}-\mathrm{i}}+\epsilon_{\mathrm{t}}
$$

At start, the test for null hypothesis of no Co-integration against alternative of the existence of a long run relationship is tested by using F-test such as;

$$
\begin{aligned}
& \mathrm{H}_{0}=\lambda_{1}=\lambda_{2}=\ldots \ldots=\lambda \mathrm{n}=0 \\
& \mathrm{H}_{1}=\lambda_{1}=\lambda_{2}=\ldots \ldots .=\lambda \mathrm{n} \neq 0
\end{aligned}
$$


If the computed F-statistic falls above the upper bound critical value of F-tabulated developed by Pesaran, the null of no Co-integration is rejected which implies that long run relationship exists among the variables of interest. On contrary, if it falls below the lower bound, then the null of no Co-integration can not be rejected. Finally, if it lies between these two bounds, the result seems inconclusive.

\section{Error Correction Mechanism (ECM):}

After the establishment of long run relationship among the variables, then in the next step, the error correction mechanism has been used to analyze the short run dynamics of the model. Error correction model was first used by Sargan (1964) and after this popularized by Engle and Granger (1987). Once Co-integration is tested and confirmed, then in the second stage, the lag order of the variables is to be selected by using Akaike Information Criteria, or Schwarz Bayesian Criteria or by Hannan-Quin Criteria or by $\mathrm{R}^{2}$ After determining the lag order, the long run coefficients of the model are estimated and then short run estimations are carried out followed by the Error Correction Model (ECM).

The ECM estimation coupled with ARDL model is obtained from equation (1) in terms of the lagged levels and the first differences of the dependent and independent variables (Pesaran, et al. 1997).

Firstly,

$$
\begin{gathered}
y_{t}=\Delta y_{t}+y_{t-1} \\
y_{t-s}=y_{t-1}-\sum_{j=1}^{s-1} \Delta y_{t-j}
\end{gathered}
$$

and similarly,

$$
\begin{aligned}
& x_{i t}=\Delta x_{i t}+x_{i t-1} \\
& w_{i t}=\Delta w_{i t}+w_{i t-1}
\end{aligned}
$$

then,

$$
x_{i t-s}=x_{i t-1}-\sum_{j=1}^{s-1} x_{i t-j}
$$

$\left(s=1,2, \ldots . q_{i}\right)$

Substituting these equations in equation (1) and after some rearrangement, the final equation of ECM is stated as;

$$
\begin{aligned}
& \Delta y_{t}=-\phi\left(1, p^{\wedge}\right) E C_{t-1}+\sum_{i=1}^{k} \beta_{i 0} \Delta x_{i t}+\delta \Delta w_{t}-\sum_{j=1}^{p^{\wedge}-1} \phi_{j^{*}} \Delta y_{t-j}- \\
& \sum_{i=1}^{k} \sum_{j=1}^{q_{i}^{\wedge}-1} \beta_{i j^{*}} \Delta x_{i t-j}+\mu_{t}
\end{aligned}
$$

where $E C_{t-1}$ is the error correction term,

$$
E C_{t-1}=y_{t}-\sum_{i=1}^{k} \theta_{i} x_{i t}-\psi w_{t}, \quad \phi_{j}^{*} \text { and } \beta_{i j}{ }^{*} \text { are the co-efficients of short run model (ECM). }
$$

The domestic savings are specified in the form of ARDL (Autoregressive Distributed Lag) model in such a general form.

$$
\begin{aligned}
& \square L D S=\alpha_{0}+\sum_{i=1}^{m} \gamma_{i} \square L D S_{t-i}+\sum_{i=1}^{m} \delta_{i} \square R R I D_{t-i}+\sum_{i=1}^{m} \eta_{i} \square L R G D P_{t-i} \\
& +\sum_{i=1}^{m} \phi_{i} \square L T O T_{t-i}+\sum_{i=1}^{m} \xi_{i} \square L T R R M_{t-i}+\lambda_{1} L D S_{t-1}+\lambda_{2} R R I D_{t-1}+ \\
& \lambda_{3} L R G D P_{t-1}+\lambda_{4} L T O T_{t-1}+\lambda_{5} L T R R M_{t-1}+\beta_{0} L B D+\zeta E C_{t-1}
\end{aligned}
$$

In the above equation, the terms with the summation signs represent the error correction dynamics while the terms with $\lambda$ s show the long run relationship between variables.

\section{Empirical Results:}

In order to scrutinize the integrating level of variables, standard tests like DF-GLS, and Ng-Perron are employed. Mostly in the literature, to find out the order of integration ADF (Dicky \& Fuller, 1979) and PP (Philips \& Perron, 
1988) tests are often employed extensively. Due to their poor size and power properties, both tests are not reliable for small sample data set (Dejong et al, 1992 and Harris, 2003). These tests seem to over-reject the null hypotheses when it is true and accept it when it is false. While the newly proposed tests such as Dicky-Fuller generalized least square (DF-GLS) de-trending test developed by Elliot et al. (1996) and Ng-Perron test following Ng-Perron (2001) seem to solve this arising problem.

On the assumption that there is need to test the order of integration of variable $X_{t}$, Elliot et al. (1996), enhance the power of ADF test by de-trending procedure and DF-GLS test is based on null hypothesis $H_{0}: \delta_{0}^{*}=0$ in the regression;

$$
\Delta X_{t}^{d}=\delta^{*} X_{t-1}^{d}+\delta_{1}^{*} \Delta X_{t-1}^{d}+\ldots \ldots . .+\delta_{p-1}^{*} \Delta X_{t-p+1}^{d}+\eta_{t}
$$

where $X_{t}^{d}$ is the de-trended series and null hypotheses of this test is that $X_{t}$ has a random walk trend, possibly with drift as follows;

$$
X_{t}^{d}=X_{t}-\hat{\varphi}_{0}-\hat{\varphi}_{1} t
$$

Basically, two hypotheses are proposed (i) $X_{t}$ is stationary about a linear time trend and (ii) it is stationary with a non-zero mean, but with no linear time trend. Considering the alternative hypotheses, DF-GLS test is performed by first estimating the intercept and trend utilizing the generalized least square technique.

Recently, Ng-Perron (2001) has developed four test statistics utilizing GLS de-trended data $D_{t}^{d}$. The calculated values of these tests based on forms of Phillips-Perron (1988) $Z_{a}$ and $Z_{t}$ statistics, the Bhargava (1986) $R_{1}$ statistics and Elliot, Rotherberg and Stock (1996), created optimal test statistics. The terms are defined as follows;

$$
k=\sum_{t=2}^{T}\left(D_{t-1}^{d}\right)^{2} / T^{2}
$$

while de-trended GLS tailored statistics are as below;

$$
\begin{gathered}
M Z_{a}^{d}=\left(T^{-1}\left(D_{T}^{d}\right)^{2}-f_{\mathrm{o}}\right) /(2 k), M Z_{t}^{d}=M Z_{a} \times M S B, M S B^{d}=\left(k / f_{\mathrm{o}}\right)^{1 / 2}, \\
M P_{T}^{d}=\left\{\begin{array}{c}
-2 \\
\left(c^{k-}-c^{T^{-1}}\left(D_{T}^{d}\right)^{2} / f_{\mathrm{o}}, \text { and },\left(c^{-2}+(1-\bar{c}) T^{-1}\left(D_{T}^{d}\right)^{2} / f_{\mathrm{o}}\right.\right.
\end{array}\right.
\end{gathered}
$$

If $x_{t}=(1)$ in the first case, then $x_{t}=(1, t)$ will be in second case. $\left(\bar{\alpha}=-7\right.$, If $x_{t}=\{1\}$ and $\bar{c}=-13.7 \bar{\alpha}=-7$, If $\left.x_{t}=\{1, t\}\right)$

The results of DF-GLS and Ng-Perron Unit Root tests for checking the stationary of the data are shown in table1. Insert Table 1 Here

The results of DF-GLS and Ng-Perron tests show that the two variables are stationary at level (RRID and LTRRM) because null hypothesis of the existence of unit root is rejected showing stationarity of series $\mathrm{I}(0)$. The remaining variables are non-stationary at level but become stationary after taking their first difference i.e. I(1).

First of all, at different lags on the first difference of each variable, F-Statistics is computed for the joint significance of variables with $\lambda \mathrm{s}$ signs. When 1 lag is imposed, there is a strong evidence of existence of Co-integration among the variables because the F-Calculated is 3.79, which is greater than the critical value of the F-Statistics of the upper level of the bound (3.646) at the 5 percent significance level. It is concluded from F-statistics that there exists a long run relationship among the variables.

Given the existence of long run relationship among the variables, ARDL model is estimated to see the long run and short run dynamics of the variables in equation (11). The long run and short run results are reported in table 2 and table 3 respectively.

Insert Table 2 Here

The long run statistics show that the real interest rate on deposits is a significant factor in determining the behavior of domestic savings. The coefficient of RRID (Real rate of interest on deposits) is .0202, which is positive and highly significant at 0.01 percent probability level. It shows that a 1 percent increase in real rate of interest on deposits tends to increase the domestic savings by $2.02 \%$, but coefficient is small, indicating more need for deregulation of interest rate. This positive relationship between savings and real rate of interest on deposits is consistent with the previous studies conducted by Athoukarala, (1998), Shrestha, et al. (2007), Ghatak (1997), 
McKinnon and Shaw (1973) and Khan, et al. (1992). Athukorala and Rajapatirana (1993) also examined that changes in the interest rate negatively affected the real cash holdings and positively affected the real savings (financial and total) and time deposits after these reforms. The results of this study also show a positive impact of GDP growth on domestic savings and its co-efficient is also highly significant. The co-efficients of terms of trade (LTOT) and real remittances by Pakistanis emigrants (LTRRM) show a negative relationship with domestic savings but statistically significant. The co-efficient of terms of trade (LTOT) is -.795 which demonstrates that due to deterioration in terms of trade, domestic savings decreased. Herberger, Laursen and Metzler postulated that real income falls with terms of trade deterioration and if the income elasticity is less than unity, then fall in income will reduce the savings by less than proportionately. In Pakistan, the income elasticity is less than unity but Laursen and Metzler hypothesis is not valid in Pakistan. The co-efficient of real remittances by Pakistani emigrants is -.320, which is statistically significant. This result is consistent with Athoukrala (1998). Khan (1992) also found that capital inflows have negative relationship with national savings. The co-efficient of liberalization dummy is also positive but very small and statistically significant and has positive effect on domestic savings but there is a more need of liberalization.

Insert Table 3 Here

The results of Error Correction Model are given in Table 3. The lagged error correction term Ecm $\mathrm{t}_{\mathrm{t}-1}$ is negative and highly significant. Its co-efficient (-1.27), shows a very rapid adjustment process indicating that disequilibria of the previous period shock will be rapidly adjusted to long run equilibrium in the current year. While results of the short run show that change in RRID (Real rate of interest on deposits) and its lag has negative impact on change in domestic savings due to high inflation rate. The short run impact of real rate of deposits is significant but very small on financial development, suggesting that there is a need for further liberalization of interest rate (Khan, et al. 2005). The co-efficient of lag of change in domestic savings has also positive effect on domestic savings which shows that previous year savings determine the current year savings. The co-efficient of change in gross domestic product has also positive effect on domestic savings in short run. The co-efficient of change in terms of trade and lag of this variable has also positive effect on domestic savings in short run. The co-efficient of change in total remittances has negative effect on domestic savings in short run. The co-efficient of change in lags of liberalization dummy variable has also negative effect on domestic savings.

According to Pesaran and Shin (1999), the stability of estimated co-efficient of the error correction model should also be empirically investigated. The CUSUM and CUSUMSQ stability tests are performed for estimated error correction model. A graphical representation of CUSUM and CUSUMsq is shown in Figures 1 and 2.

\section{Insert Figure 1, Figure 2 Here}

The figures show that the plots of CUSUM and CUSUMSQ statistics exist well within the critical bounds implying that all co-efficients of short run model (ECM) are stable.

\section{Conclusion:}

This study examines the interest rate savings inter relationships and the effect of financial liberalization policy on domestic savings behavior in Pakistan. The purpose of this study is to provide empirical evidence by testing McKinnon's complementarity hypothesis for Pakistan. The central point of the McKinnon-Shaw (1973) hypothesis is that a low or negative real rate of interest discourages savings and hence reduces the availability of loanable funds, inhibits investment, and ultimately lowers the rate of economic growth. On the contrary, an increase in the real interest rate may induce the savers to save more, which augments investment. This may lead to complementarity between the accumulation of financial assets and physical capital accumulation. The empirical results of the study show that the real rate of interest on deposits affects the domestic savings positively in the long run. The effect of financial liberalization is positive on domestic savings. The results strongly favor the McKinnon Shaw hypothesis. The findings are consistent with Athuokarala (1998), Sthrestha, et al. (2007) and Khan, et al. (1992).

Based on the findings of this study, it is suggested that;

- There should be political stability in the economy so that the structure of financial system gets flourished in well manners.

- There should be consistency and stability in macro economic policies which are implemented in the country in the short and long run.

- There is a need to control inflation in real terms to provide favorable environment.

- Strengthening the State Bank of Pakistan's capacity in controlling and guiding the activities of financial institutions and financial intermediaries. 


\section{References}

Athukorala, P.C. (1998), Interest Rates, Saving and Investment: Evidence from India, Journal of Oxford Development Studies, Vol. 26, No. 2.

Athukorala, P., and Rajapatirana, S. (1993), Liberalization of the Domestic Financial Market: Theoretical Issues with Evidence from Sri Lanka, International Economic Journal, Vol, 7:4, 17- 33.

Balassa, B. (1989), Financial Liberalization in Developing Countries, Policy, Planning and Research working papers, The World Bank.

Ghatak, S. (1997), Financial liberalization: The case of Sri Lanka, The Empirical Economics, Vol, 22,117-129.

Kasekende, L, A. and Atingi-Ego, M. (1999), Impact of Liberalization on Key Markets in Sub-Saharan Africa: The Case of Uganda, Journal of International Development, 11,411-436.

Khan A, H., Hasan, L. and Malik, A. (1992), Dependency Ratio, Foreign Capital Inflows and the Rate of Savings in Pakistan, The Pakistan Development Review, Vol 31:4.843-856, 1992.

Khan, M, A., A, Qayyum and Sheikh, S, A. (2005), Financial Development and Economic Growth: The case of Pakistan, The Pakistan Development Review, Vol, 44:4, 819-837.

Kemal, A, R. (2002), Regulatory framework in Pakistan, The Pakistan Development Review, Vol ,41:4, 319-332.

Mckinnon, R, I. (1973), Money and Capital in Economic Development, Washington, DC, Brooking Institute.

Pesaran, H, M. and Pesaran, B., (1997), Working with microfit 4.0: Interactive Econometric Analysis, Oxford university press.

Roubini, N. and Sala-i-Martin, X. (1992), Financial Repression and Economic Growth, Journal of Development Economics, Vol, 39, 5-30.

Shrestha, M. and Chowdhury, K. (2007), Testing Financial Liberalization Hypothesis with ARDL Modeling Approach, The Applied Financial Economics, Vol, 17, 1529-1540.

Thirlwall, A, P. (2004), The Mobilisation of Savings for Growth and Development in Developing Countries, Monetaria e Investigacion Economica.

Table.1. DF-GLS \& Ng-Perron Unit Root Test

\begin{tabular}{|c|c|c|c|c|}
\hline Variables & \multicolumn{2}{|c|}{ DF-GLS at level } & \multicolumn{2}{|c|}{ DF-GLS at $1^{\text {st }}$ difference } \\
\hline RRID & \multicolumn{2}{|c|}{-2.3152} & \multicolumn{2}{|c|}{$-5.9787 *$} \\
\hline LTRRM & \multicolumn{2}{|l|}{-2.9262} & \multicolumn{2}{|c|}{$-5.4915^{*}$} \\
\hline LDS & \multicolumn{2}{|l|}{-2.9418} & \multicolumn{2}{|c|}{$-4.3743 *$} \\
\hline LRGDP & \multicolumn{2}{|l|}{-2.1722} & \multicolumn{2}{|c|}{$-4.1514 *$} \\
\hline LTOT & \multicolumn{2}{|l|}{-2.8872} & \multicolumn{2}{|c|}{$-5.5842 *$} \\
\hline \multicolumn{5}{|c|}{ Ng-Perron at level } \\
\hline variables & $\mathrm{MZa}$ & $\mathrm{MZt}$ & MSB & MPT \\
\hline RRID & -8.328 & -1.999 & 0.240 & 11.070 \\
\hline LTRRM & -11.024 & -2.323 & 0.211 & 8.390 \\
\hline LDS & -9.878 & -2.216 & 0.224 & 9.252 \\
\hline LRGDP & -3.737 & -1.367 & 0.368 & 24.385 \\
\hline LTOT & -9.378 & -2.160 & 0.230 & 9.738 \\
\hline \multicolumn{5}{|c|}{ Ng-Perron at $1^{\text {st }}$ difference } \\
\hline RRID & $-13.177^{*}$ & -2.550 & 0.194 & 7.008 \\
\hline LTRRM & $-16.729^{*}$ & -2.891 & 0.173 & 5.454 \\
\hline LDS & $-12.207 *$ & -2.469 & 0.202 & 7.472 \\
\hline LRGDP & $-13.631 *$ & -2.472 & 0.181 & 7.451 \\
\hline LTOT & $-13.829^{*}$ & -2.628 & 0.190 & 6.597 \\
\hline
\end{tabular}


Table 2. ARDL $(1,1,0,1,0)$ Long Run Results

\begin{tabular}{|l|l|l|l|}
\hline \multicolumn{5}{|c|}{ Dependent } & Variable LDS \\
\hline Regressor & Coefficient & S.E. & T-Ratio \\
\hline RRID & $0.0202 * * *$ & 0.003 & 5.577 \\
\hline LRGDP & $1.392 * * *$ & 0.106 & 13.088 \\
\hline LTOT & $-0.794 * * *$ & 0.246 & -3.218 \\
\hline LTRRM & $-0.320 * * *$ & 0.077 & -4.144 \\
\hline LBD & $0.216 * * *$ & 0.047 & 4.601 \\
\hline INPT & 0.390 & 0.811 & 0.480 \\
\hline
\end{tabular}

*** shows the coefficient is significantly different from zero at $(0.01 \mathrm{p})$ level.

** shows the coefficient is significantly different from zero at $(0.05 \mathrm{p})$ level.

Table 3. ARDL $(1,1,0,1,0)$ Error Correction Mechanism (Short run Dynamics)

\begin{tabular}{|l|l|l|l|}
\hline \multicolumn{4}{|c|}{ Dependent Variable DLDS } \\
\hline Regressor & Coefficient & Standard Error & T-Ratio \\
\hline dLDS & $0.513^{* * *}$ & 0.127 & 4.031 \\
\hline dRRID & $0.009 * * *$ & 0.003 & 2.697 \\
\hline dLRGDP & $1.769 * * *$ & 0.204 & 8.637 \\
\hline dLTOT & $0.896 * *$ & 0.354 & 2.531 \\
\hline dLBD & $-0.170^{* * *}$ & 0.045 & -3.736 \\
\hline dINPT & 0.495 & 1.025 & 0.483 \\
\hline Ecm(-1) & $-1.270^{* * *}$ & 0.133 & -9.496 \\
\hline
\end{tabular}

*** showed that coefficient is significantly different from zero at $(0.01 \mathrm{p})$ level.

** showed that coefficient is significantly different from zero at $(0.05 \mathrm{p})$ level.
$\mathbf{R}^{2}=.95$
$R^{2} \mathbf{a d j}=.88$
F-stat $=18.35$
Log.L $=79.49$
$\mathrm{AIC}=60.487$
$\mathrm{SBC}=46.864$
$\mathrm{DW}=\mathbf{2 . 1 5 6}$

Plot of Cumulative Sum of Recursive Residuals

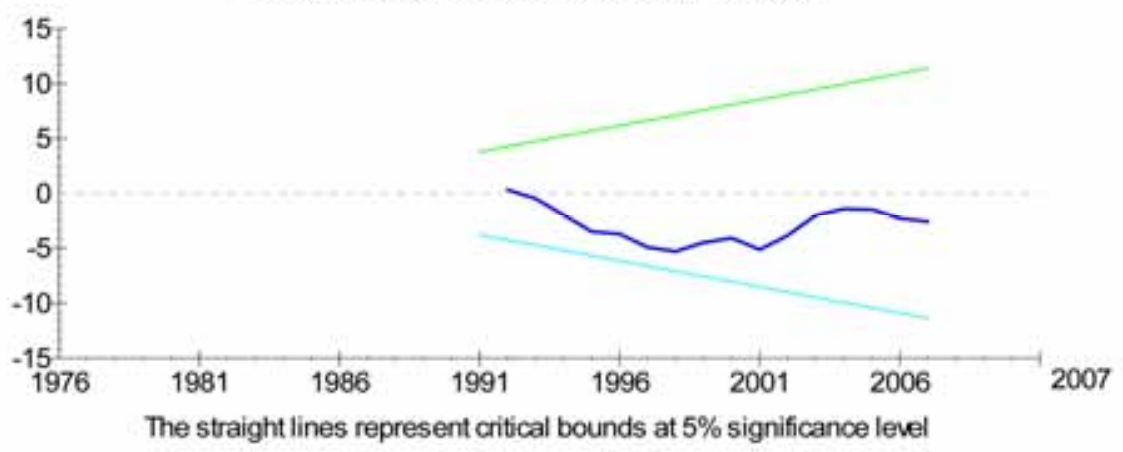

Figure 1. Plot of CUSUM of Domestic Savings Function

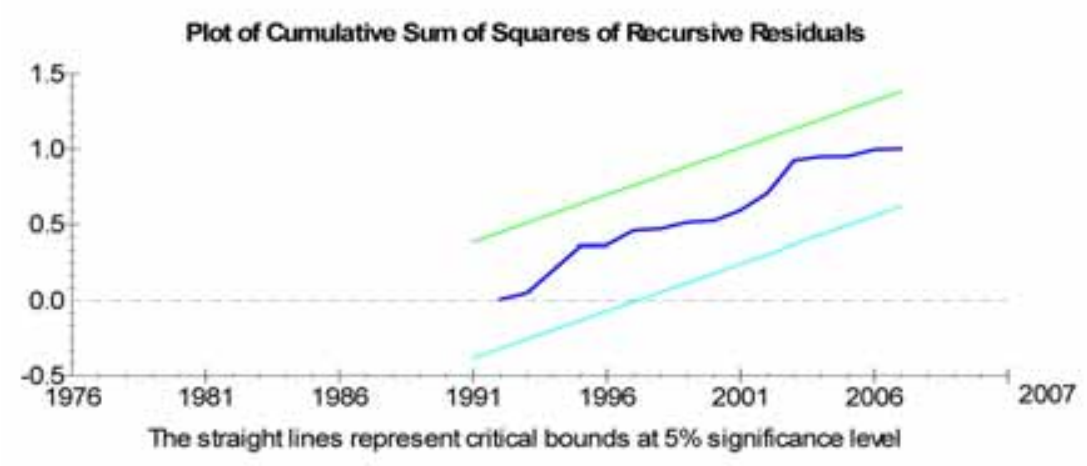

Figure 2. Plot of CUSUMSQ of Domestic Savings Function 